\title{
Environmental value losses as impacts of natural resources utilization of in coal open mining
}

\author{
Restu Juniah ${ }^{1}$, Rinaldy Dalimi ${ }^{2}$, M. Suparmoko ${ }^{3}$, Setyo S Moersidik ${ }^{4}$,and Harry Waristian ${ }^{1}$ \\ ${ }^{1}$ Department of Mining Engineering Faculty of Engineering Sriwijaya University, 30139 Palembang, Indonesia \\ ${ }^{2}$ Regional Developments Studies, Electrical Engineering, University of Indonesia, 16424 Jakarta, Indonesia \\ ${ }^{3}$ Environmental Economics, University of Budi Luhur, 12260 Jakarta, Indonesia \\ ${ }^{4}$ Regional Developments, Environmental Science, University of Indonesia, 16424 Jakarta, Indonesia
}

\begin{abstract}
Mining industry provides benefits to the state in mining as a source of state revenue and foreign exchange earner, producing raw materials for the industrial, infrastructure and socio-economic facilities, and employment providers. Utilization of natural resources in openly coal mining in the forest did to get these benefits, but on the other hand cause environmental harm. Land clearing activities in coal mining, open forest vegetation is causing the loss of economic benefits of forest. Exploitation of coal caused the shrinking amount of coal (coal depletion). Although revegetation activities have been conducted on coal mined land, those would still cause harm to the environment. The research conducted at the site of coal mining PT Bukit Asam (PTBA) South Sumatra Indonesia using quantitative methods of Net Present Value (NPV) aims to assess the value of environmental damages incurred as a result of the utilization of natural resources in coal strip mine in forest areas. The calculation of forest benefit in and after the forest recovery period is using time dimensions that has innovated in this study. The results found for the environmentalloss duringlife of mine for a period of time 1997-2023 PV 2009 amounted to Rp 73.98 trillion,-
\end{abstract}

\section{Introduction}

Environmentally sound development becomes an important requirement for any nation that wants the preservation of natural resources. Therefore, natural resources need to be preserved and maintained for the survival of human kind in the present, and for the next generations. Forest destruction has led to reduction in the value of forest benefits.

Damage of the forest will also damage its ecosystem and its surrounding areas, as well as destroying all living systems. According to Reference [1] a lot of forest ecosystem services value clearly can not be known its monetary value. The impact of these policies affect the forest use, including for open pit coal mining activities more consider the financially benefits, so that the rate of degradation become faster.

Constanza et al. [1] stated that the increased of degradation threatens the value of the benefits of forest ecosystems. Use of natural resources by open mining coal land clearing activities and coal exploitation activities pose a negative externality on the function of forest ecosystems, such as forests function as a provider of natural resources such as timber resources and coal resources contained in the forest.

The loss of this function results in loss of economic benefit to the forest so that the resulting loss of forest and coal depletion. Revegetation activities on coal mined lands to forests provide economic benefits in the form of the benefits of revegetation. But unfortunately coal mining activity in Indonesia including PT Bukit Asam South Sumatera not account for the losses suffered as a result of the loss of forest and coal depletion. Similarly, the value of the environmental benefits derived from the activities of revegetation.

In accordance with this study seem it necessary to assess economic losses of natural resources and the environment due to the use of natural resources in coal mines open in logged-over secondary forests on coal stock loss and the loss of value of the economic benefits of forests.

\section{Material and methods}

\subsection{Study area}

PTBA founded on 1981, now the company is the $6^{\text {th }}$ biggest mining company in Indonesia. Mining systems used in PTBA to exploit the natural resources of coal using open pit methods. Mining area of PT. Bukit Asam (Persero), Tbk. PTBA's coal mining consists of three mining blocks namely Tambang Air Laya (TAL), Tambang Bangko Barat (TBB), and the Tambang MuaraTiga Mine Besar (MTB). This study focused on

\footnotetext{
${ }^{*}$ Corresponding author: author@e-mail.org
} 
TAL Block, located in District Lawang Kidul Muara District Enim, South Sumatra Province, Indonesia.

\subsection{Methodology}

Based on field investigation, the research conducted is environmental filed. Research conducted by surveys directly to the field of TAL PTBA to verify the secondary data obtained by instasional studies, and direct observation conducted to examine the effects of externalities of coal mining activities on the environment. Instational Survey conducted by visiting institutions associated with this study.

The population of study is a block of the mines in the coal mine site PTBA which consists of (1) Tambang Air Laya (TAL), (2) Tambang Bangko Barat (TBB), (3) Tambang Muara Tiga Besar (MTB). Samples were taken in Tambang Air Laya block. Sample determination is conducted by purposive sampling [8]. Determination based purposive sample on consideration of: (1) how long the PTBA coal mining blocks has been mined and reclaimed; searched the first block mined and reclaimed, and to know the influence of the distribution of the effects of these activities on the environment.

The study is a quantitative method to calculate the net present value (NPV) of the benefits and costs associated with the externalities of the utilization of natural resources in the open pit coal mining to the environment.

\section{Economic loss assessment of natural resources and environmental impacts of natural resource utilization of open pit coal mining}

The utilization of natural resources of coal in the open pit is one of the activities that alter land conversion and forest ecosystems can be a threat to the economic value of natural resources and environment. The conceptual framework of the research is shown in figure 1.

Broadly speaking, the calculation of depletion and degradation of natural resources has been done in previous studies.

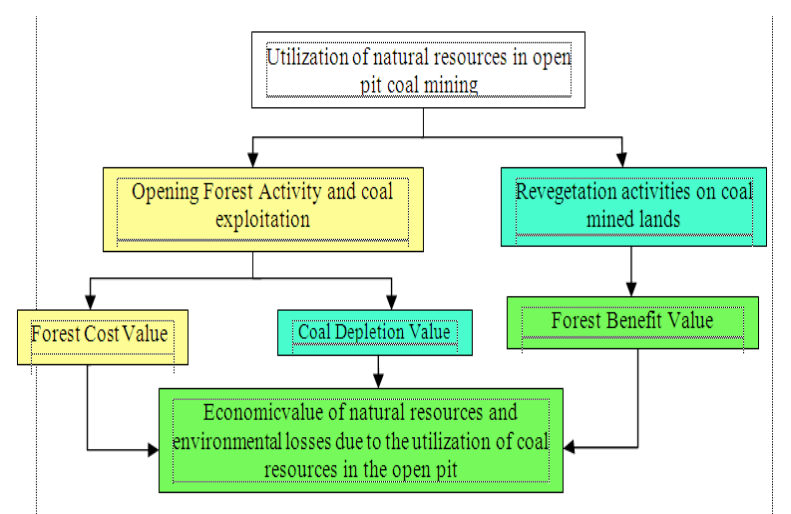

Fig .1. The conceptual framework

In this study, the calculation of depletion of natural resources is still being done on coal resource depletion calculation and standing timber logged-over secondary forests. The development of the previous studies is to provide an economic assessment of forest loss, the study calculated the dimension of time is when the forest opened up the forest revegetation approach requires its original estimated recovery time for 15 years.

The economic value of each component (the value of coal depletion, loss of forests, indigo benefits of revegetation) next calculated the present value (present value) in 2009. Present value to the value of each component are summed to obtain a total economic value (NET) loss of natural resources and the environment due to the use of natural resources in the coal mine open.

Calculations are made up of natural resource depletion and environmental losses, the benefits of revegetation on coal mined lands and forest benefits to $n$ after the end of revegetation activities on coal mined lands (during the recovery period of 15 years), with the calculation of the time dimension is a unitary concept of determination environmental losses due to natural resource use coal strip mine the state of the art in this research complements a lack of previous research studies lack.

Value of forest loss is not taken into account only in the dimension of space, but also with the calculation of time dimensions (15 years), adjusted to the time of recovery (restoration) secondary forest logged over to approach its original state, and the mature eucalyptus plants are most abundant in the location TAL PTBA and can be extracted as eucalyptus oil, as well as the loss values for each component and forest benefits over the life of the mine and the benefits of forests to $t$ years after the end of the forest restoration activities carried out calculations to obtain the present value of the total economic value as the novelty of this study are as follows:

a. Value of coal depletion

$$
V D_{c}=\sum_{p=1}^{p=q}\left(D_{c}\right) \frac{1}{(1+r)^{t}}
$$

where:

$$
\begin{array}{ll}
\mathrm{VD}_{\mathrm{c}} & =\text { value of coal depletion }(\mathrm{Rp}) \\
\mathrm{D}_{\mathrm{c}} & =\text { coal depletion }(\mathrm{Rp}) \\
\mathrm{P} & =1=\text { first year of exploitation= } \\
& 1997 \\
= & 1,2,3, \ldots \ldots \mathrm{p}=\mathrm{q} \\
\mathrm{Q} & =1 \text { last year of explitation }=2023 \\
\mathrm{r} & =\text { interest rate }(\%) \\
\mathrm{t} & \text { periods of coal depletion time } \\
& \text { since the first calculation of } \\
& \text { present value (year 2009) }
\end{array}
$$

b. Value of logged over secondary forest loss

$$
V F L_{s l o}=\sum_{p=1}^{p=q}\left(F L_{s l o}\right) \frac{1}{(1+r)^{t}}
$$

$$
\begin{aligned}
& \text { where: } \\
& \begin{aligned}
\mathrm{VFL}_{\mathrm{sl}} & =\text { value of forest loss }(\mathrm{Rp}) \\
\mathrm{FL}_{\mathrm{slo}} & =\text { forest loss }(\mathrm{Rp}) \\
\mathrm{p} & =1=\text { first year of exploitation }=1997 \\
& =1,2,3, \ldots \ldots \mathrm{p}=\mathrm{q} \\
\mathrm{q} & =\text { last year of explitation }=2023
\end{aligned}
\end{aligned}
$$


$\mathrm{r}=$ interest rate $(\%)$

$\mathrm{t}=$ period of forest loss time since the first calculation of present value (year 2009)

with, the forest loss use the equation below:

$$
F L_{\text {slo }}=F A O_{\text {slo }} x V F_{\text {slo }}
$$

Source: Restu Juniah, 2012

where:

$$
\begin{array}{ll}
\mathrm{FL}_{\text {slo }} & =\text { forest loss }(\mathrm{Rp}) \\
\mathrm{FAO}_{\text {slo }} & =\text { forest area opened (ha) } \\
\mathrm{VF}_{\text {slo }} & =\text { value of secondary forest logged over } \\
& \text { /ha/year (Rp) }
\end{array}
$$

c. Value of logged-over secondary forest benefits

$$
V F B_{\text {slo }}=\sum_{p=1}^{p=q}\left(F B_{\text {slo }}\right) \frac{1}{(1+r)^{t}}
$$

Source: Restu Juniah, 2012

$$
\text { where: }
$$

$$
\begin{array}{cl}
\mathrm{VFB}_{\text {slo }} & =\text { value of logged over secondary } \\
& \text { forest } / \text { revegetation benefit }(\mathrm{Rp}) \\
& =\text { benefit of logged over secondary } \\
& \text { forest } / \text { revegetation benefit }(\mathrm{Rp}) \\
& =1=\text { first year of exploitation }=1997 \\
\mathrm{p} & 1,2,3, \ldots \ldots \mathrm{p}=\mathrm{q} \\
\mathrm{Q} & =\text { last year of explitation }=2023 \\
\mathrm{r} & =\text { interest rate }(\%) \\
\mathrm{t} & =\text { period of forest benefit time since the } \\
& \text { first calculation of present value (year } \\
& \text { 2009) }
\end{array}
$$

\section{d. Result}

Utilization of natural resources by open pit coal are conducting clearing forests through land clearing and revegetation on coal mined lands as an externality impacts on natural resources and the environment.

\section{Impacts of forest clearing and revegetation of coal mined lands.}

The forest clearing activities at the site of TAL PTBA conducted in order to clear mined lands for the excavation of coal. After the coal excavation accomplished the area there is an empty land called coal mined lands. With the end of coal excavation at the least after 6 months, then the coal mined lands should be started with revegetation (Government of RI Regulation No. 78 year 2010). The forest area and opened in locations revegetated of TAL PTBA from1997 until 2023 is Area of forest revegetated $(1,374.5 \mathrm{Ha})$, and Area of forest opened $(3,106.59 \mathrm{Ha})$.

\subsection{Calculation methode of value of forest benefits}

Valuation losses of natural resources and environmental externalities arising from the use of natural resources in the open pit coal use calculation methods that have been modified from previous studies [10] and those found in this study. Method of calculation used to determine the percentage of forest benefits revegetation approach for the 15-year secondary forest recovery. Percentage revegetation approaches do given the plant to become mature through the process of growth each year. 15-year time horizon used is based on eucalyptus plants most dominating in the area of revegetationat TA PTBA can be extracted to be taken advantage at the ripe age of 15 years, and according to [7] it would take 15 years for the recovery of logged-over secondary forests in the TAL PTBA site.

Value of environment benefits obtained from each year revegetation percentage for 15 years time horizon. Similarly for the year to 16 and so on for the operational life of the mine will continue to value the environmental benefits obtained in a sustainable manner. If the value of the benefit during forest restoration continues to increase each year in accordance with the process of plant growth up to $15^{\text {th }}$ year (the printed image and his broken red line), then for $n$ years after the end of the recovery period $\left(16^{\text {th }}\right.$ year an so on) a decline in the value of benefits cumulative environmental (printed lines and blue arrows). It is assumed that with the increasing age of the plant after the mature will decrease the ability to be productive. The diagram of growth process and counting revegetation of forest benefits during forest restoration, and year after the recovery period) in TAL Location PTBA is shown in Figure 2.

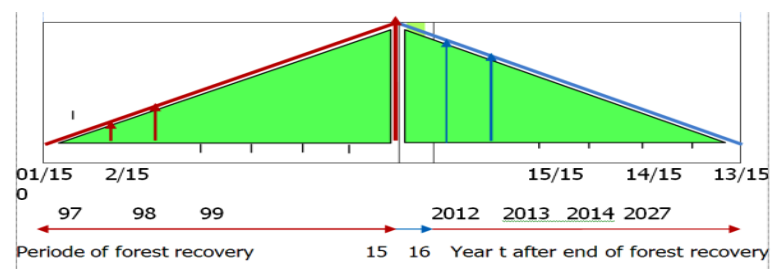

Fig.2. Diagram of revegetation growth process and counting for the forests benefit and forest restoration into the year $t$ recovery on tal ptba location.

Forest benefits use the following equation:

$$
\mathrm{FB}_{\text {slo }}=\frac{\mathrm{M}-\mathrm{m}}{\mathrm{M}} \times \mathrm{RFA}_{\text {slo }} \times \mathrm{VF}_{\text {slo }}
$$

Persentage of revegetation

Source: Restu Juniah, 2012

where:

$$
\begin{array}{ll}
\mathrm{FB}_{\text {slo }} & =\text { benefits of secondary forests looged } \\
& \text { over }(\mathrm{Rp}) \\
\mathrm{RFA}_{\mathrm{sl}} & =\text { forest area revegetated (ha) } \\
\mathrm{o}_{\text {slo }} & =\text { value of secondary forest logged over } \\
& / \text { ha/year }(\mathrm{Rp}) \\
\mathrm{M} & =\text { periode of forest recovery }=15 \text { years } \\
\mathrm{m} & =\text { year } \mathrm{n} \text { of forest recovery }
\end{array}
$$

Calculation of value of forest benefits year of $t$ after period of forest recovery 15 year use the equitation 6 .

where:

$$
\mathrm{FB}_{\mathrm{t}, \mathrm{T}+1}=\mathrm{FB}_{\mathrm{t}, \mathrm{T}}-\left(\mathrm{M}-\mathrm{t} / \mathrm{M} \times \mathrm{FB}_{\mathrm{t}, \mathrm{T}}\right)
$$

$\mathrm{FB}_{\mathrm{t}, \mathrm{T}+1}=$ forest benefit at the end of recovery period (Rp) 


$$
\begin{array}{ll}
\mathrm{FB}_{\mathrm{t}, \mathrm{T}} & =\text { forest benefit at the last year of } \\
& \text { recovery }(\mathrm{Rp}) \\
\mathrm{T} & =\text { last year of recovery period } \\
\mathrm{T} & =1,2 \ldots, \mathrm{M}-1 \\
\mathrm{M} & =\text { periode of forest recovery }=15 \text { years }
\end{array}
$$

\subsection{Assessment of natural resources and environmental losses due to natural resource utilization activities of coal open mining.}

Assessment of natural resources and environmental losses due to the utilization of natural resources in coal open mining to assess and determine losses to the environment as a result of the utilization of natural resources in coal strip mine that caused the depletion of coal and forest loss. While the total economic value ((TEV) is obtained by subtracting the value of the loss (the value of coal depletion and loss of forests) to the value of forest benefits obtained through the benefits of revegetation on coal mined lands. Assessment was conducted on the following components of the value of coal depletion, loss of value, value of forest benefits.

a. Value of coal depletion

Coal mining activities with the exploitation of coalcausedcoal depletion, coal reserves shrinking resulting inthe loss of ecosystem servicesto provide thenatural resourcesof coal. Calculation of coal depletion annually using the equation: 2 . While the economic rent of coal obtained Rp 242,325,

Based on the calculations, value of coal depletion in 1997 - 2023 PV 2009 logged over TAL PTBA location is $\operatorname{Rp} 73,474,494,298,342$, - or 73.5 trillion rupiah. Thus, this study found that coal depletion occurred in coal mines during mine life TAL PTBA years 1997-2023 PV 2009 as externalities of natural resource utilization activities of coal open mining valued at 73.5 trillion rupiah.

\section{b. Value of forest loss}

The forest clearing activities at the TAL PTBA site since 1997 has been done in stages in accordance with the stages of mining. The need to internalize external costs into the cost of production due to the cost required to address the environmental damage is much greater than the cost of prevention. The results of Sudirman (2011) found no environmental damage costs incurred as externalities PT Indominco Indonesia coal mining in protected forests. Sudirman assess the cost of environmental damage caused by coal mining in protected forests, whereas in this study examined the effect of external costs of coal mining activities secondary forest areas. Costing forest at TAL PTBA location uses equations: 4. Based on calculations that have been made to known the economic value of forests per ha per year in TAL PTBA coal mining is Rp. $39,082,000$, -. Using equation 3 by assuming the interest rate of 7\% (the average rate of Bank of Indonesia, 2011) and remains valid for a year, the value of forests costs over the life of the mine in 1997-2023 PV 2009 for the 15-year restoration of logged over forest in TAL PTBA site is $\mathrm{Rp} 834,001,622,078.003$, - or 834 billion rupiah. Thus, this study found the loss suffered by secondary logged-over forests in the coal mines during mine life of TAL PTBA years 1997-2023 PV 2009 as externalities arising from the utilization of natural resources in the open pit coal worth 834 billion rupiah.

c. Value of forest benefit.

Forest is a natural resource which is very important and useful for life and living either directly or indirectly, that contains the value of services for the life of the environment service. Previous research by [9] stated to get the value of $1,835.83$ U.S. \$ / ha/ year as value of secondary forest services in Indonesia. Similarly, research in Thailand by [4] suggests a value of USD $756.16 /$ ha/year obtained from externalities reforestation with type Eucalypthuscamaldulensia. Compensation for people who lost access to the forest of USD 673,000 per year and the value of farmers' losses due to the flood of USD 71,000 per year in Madagascar shows the value of environmental services of forests [3]. Value of the external benefits in this study was obtained from the benefits of revegetation at the TAL PTBA site. Revegetation activities at TAL PTBAsite are performed each year in accordance with the annual plan of environmental management of TAL PTBA. Revegetation activities is calculated by assuming that (1) the economic value of plants emerged a yearafter the implementation of revegetation activities initiated by 15 year recovery period, (2) After 15 years of restoration at the TAL PTBA site, revegetation activities not yet done, and no logging activity, but the forest still preserved until coal post-mining, so in year 16 and post-mining coal revegetation activities still providing value of benefits.

The calculation of the benefits of forest each year in TAL PTBA coal mines using equation 6. Using equations 7 , assuming the rate of interest $7 \%$ (the average rate of Bank of Indonesia, 2011) and remains valid for a year, and the economic value of forests per ha per year in coal mines TAL PTBA is Rp 39,082,000, discovered the value of forest benefits are environmental benefits over the life of the mine in 1997-2023 PV 2009 with a 15-year restoration of logged forest in PTBA TAL site of Rp 324,233,514,093, - or 324 billion rupiah.

Thus, this study found that the benefits arising from the revegetation on coal mined lands in the coal mines during mine life TAL PTBA years 1997-2023 PV 2009 as externalities of natural resource utilization activities of coal open mining worth 324 billion dollars. Value of coal depletion, value of forest cost, value of forest benefits, and value loss in the year 1997-2023 PV TAL PTBA's coal mines in South Sumatra Province, Indonesia.

Land conversion activities that alter forest ecosystems such as the utilization of coal resources in open pit mines pose externalities on natural resources and the environment that cause harm to the environment. Environmental losses that resulting from the utilization of open pit coal mining as shown in the Table 1 above as 
a sum of 73.98 trillion rupiah. Revegetation activities on coal mined lands are expected to recover the loss of environmental benefits can only benefit the forest worth 324.23 billion rupiah. Value of this benefit is very small compared with the losses suffered by the environment worth 73.98 trillion rupiah.

Table 1. Environmental losses

\begin{tabular}{|c|c|c|c|c|}
\hline Year & $\begin{array}{l}\text { Forest Loss PV } \\
2009 \text { (a) }\end{array}$ & \begin{tabular}{|c} 
Depletion of Coal PV \\
2009 (b) \\
\end{tabular} & $\begin{array}{l}\text { Forest Benefits } \\
\text { PV } 2009 \text { (c) }\end{array}$ & $\begin{array}{l}\text { Environmental Losses } \\
(\mathrm{a}+\mathrm{b})-\mathrm{c}\end{array}$ \\
\hline 1997 & $32,385,212,266$ & $763,104,135,591$ & - & $795,489,347,856.97$ \\
\hline 1998 & $32,898,428,785$ & $741,156,209,096$ & $21,300,027,319$ & $752,754,610,562.09$ \\
\hline 1999 & $33,328,908,303$ & $894,950,539,672$ & $19,017,286,295$ & $909,262,161,679.71$ \\
\hline 2000 & $33,949,385,774$ & $792,599,074,362$ & $18,708,592,124$ & $807,839,868,012.19$ \\
\hline 2001 & $34,487,389,043$ & $781,868,058,132$ & $18,404,911,091$ & $797,950,536,084.43$ \\
\hline 2002 & $17,797,496,341$ & $862,635,485,539$ & $18,106,159,460$ & $862,326,822,419.51$ \\
\hline 2003 & $30,865,683,990$ & $985,458,196,909$ & $10,475,303,648$ & $1,005,848,577,250.44$ \\
\hline 2004 & $36,325,138,652$ & $864,656,381,795$ & $18,484,621,823$ & $882,496,898,625.05$ \\
\hline 2005 & $36,045,560,895$ & $908,395,918,328$ & $20,474,485,923$ & $923,966,993,299.14$ \\
\hline 2006 & $48,384,868,936$ & $958,621,294,118$ & $19,972,191,292$ & $987,033,971,762.37$ \\
\hline 2007 & $39,899,562,069$ & $974,517,243,680$ & $28,221,939,119$ & $986,194,866,629.74$ \\
\hline 2008 & $5,122,695,421$ & $1,061,285,503,770$ & $13,553,425,005$ & $1,052,854,774,186.16$ \\
\hline 2009 & $8,641,994,298$ & $1,279,476,000,000$ & $10,357,937,753$ & $1,277,760,056,545.28$ \\
\hline 2010 & $3,552,435,842$ & $2,544,124,427,664$ & $10,389,688,458$ & $2,537,287,175,047.11$ \\
\hline 2011 & $1,403,861,859$ & $2,747,654,381,877$ & $11,638,498,935$ & $2,737,419,744,800.64$ \\
\hline 2012 & $13,058,023,230$ & $2,967,466,732,427$ & $10,858,414,843$ & $2,969,666,340,814.18$ \\
\hline 2013 & $3,486,788,579$ & $3,204,864,071,021$ & $10,110,677,323$ & $3,198,240,182,277.53$ \\
\hline 2014 & 0 & $3,461,253,196,703$ & $9,393,170,245$ & $3,451,860,026,457.78$ \\
\hline 2015 & $13,958,524,170$ & $3,738,153,452,439$ & $8,703,915,916$ & $3,743,408,060,693.01$ \\
\hline 2016 & $9,013,150,696$ & $4,037,205,728,634$ & $8,041,066,026$ & $4,038,177,813,304.02$ \\
\hline 2017 & 0 & $4,360,182,186,925$ & $7,402,893,182$ & $4,352,779,293,743.06$ \\
\hline 2018 & $78,310,010,140$ & $4,708,996,761,879$ & $6,769,096,030$ & $4,780,537,675,988.71$ \\
\hline 2019 & $73,186,925,365$ & $5,085,716,502,829$ & $6,158,075,278$ & $5,152,745,352,915.68$ \\
\hline 2020 & $68,398,995,668$ & $5,492,573,823,055$ & $5,568,340,880$ & $5,555,404,477,843.22$ \\
\hline 2021 & $63,924,295,017$ & $5,931,979,728,900$ & $4,998,500,271$ & $5,990,905,523,645.46$ \\
\hline 2022 & $59,742,331,792$ & $6,406,538,107,212$ & $4,447,251,988$ & $6,461,833,187,014.87$ \\
\hline 2023 & $55,833,954,945$ & $6,919,061,155,788$ & $3,913,379,711$ & $6,970,981,731,022.71$ \\
\hline Total & $834,001,622,078$ & $73,474,494,298,342$ & $324,233,514,094$ & $73,984,262,406,325.80$ \\
\hline
\end{tabular}

Assessment of natural resources and environmental losses due to natural resource utilization activities of coal open mining can be applied by: 1) Government as policy makers should internalize the environmental cost into coal mining feasibility study using open pit methods. The Government, should implieda policy to internalizethe external cost (environmental cost) in the feasibility study of coal mining activity with open pit method, 2) Openly coal mining business in general should determine the value of losses incurred as externalities of coal open mining activities.

\section{Conclusion}

The calculation of forest benefit in and after the forest recovery period is using time dimensions has been innovated in this study. The results found for the environmentalloss during life of mine for a period of time 1997-2023 PV 2009 amounted to Rp 73.98 trillion,. The results of this study indicate that such large losses suffered as a result of the utilization of the open pit coal mining apart due to the loss of forest resources worth 834 billion rupiah also caused the loss of coal stock in the nature worth 73.47 trillion rupiah. With the findings of this study should coal mining operation account for losses arising as environmental externalities of natural resource utilization activities of coal open mining.

\section{References}

1. R. Costanza, , R. D’Arge, ,R. de Groot, S. Farber, , Grasso, M., Hannon, B., Limburg,K., Naeem, S., O'neill, R., Paruelo, J., Raskin, R., Ssutton, P., \& van den Belt, M. Nature, 387 : 253-260 (1997)

2. Directorate General of Mineral and Coal. Annual Report Management \&Environmental Monitoring Tambang Air LayaTanjungEnim- Sumatera Selatan (2012)

3. Kramer, RA., N. Sharna., and M. Munasinghe. World Bank Environment Paper. Number 13. The World Bank, Washington DC (1995)

4. A. Niskanen, Value of External Environmental Impact of Reforestation (1998)

5. In Thailand. Ecological Economic Journal No. 26 (1998).

6. Government Regulation Number. 78 Year 2010 about Reclamation and Mine Closing. Directorate General of Mineral. Ministry of Energy and Minaral Resource Republic of Indonesia (2010)

7. A. Stenger, P. Harou, \& S. Navrud, Journal of Forest Economics, 15, 1-14 (2009)

8. Sukandarrumidi, Research Methodology. ${ }^{\text {rd }}$ Edition, Gajahmada University Press, Yogyakarta, ISBN: 979-420-508-7 (2006)

9. Suparmoko, Journal of Development Economic (Economic Study on Developing Countries) Vol. 13 No.3 December 2008 Pages:217-229. (2008).

10. Sudirman, Valuation econict of Mining Impact" disertation, PSIL UI (2011) 